\title{
Reproductive pattern of the reef-building coral Pavona gigantea (Scleractinia: Agariciidae) off southwestern Mexico
}

\section{Patrón reproductivo del coral arrecifal Pavona gigantea (Scleractinia: Agariciidae) frente al sudoeste de México}

\author{
Jeimy Denisse Santiago-Valentín ${ }^{1}$, Alma Paola Rodríguez-Troncoso ${ }^{1}$, Eugenio Carpizo-Ituarte ${ }^{2}$, \\ Francisco Benítez-Villalobos ${ }^{3}$, Pablo Torres-Hernández ${ }^{3}$, Andrés López-Pérez ${ }^{4 *}$ \\ ${ }^{1}$ Centro Universitario de la Costa, Universidad de Guadalajara, Av. Universidad No. 203, Puerto Vallarta, \\ 48280 Jalisco, México. \\ 2 Instituto de Investigaciones Oceanológicas, Universidad Autónoma de Baja California, Carretera \\ Transpeninsular Ensenada-Tijuana \#3917, Fraccionamiento Playitas, 22860 Ensenada, Baja California, \\ México. \\ ${ }^{3}$ Universidad del Mar, Ciudad Universitaria, Distrito de San Pedro Pochutla, 70902 Puerto Ángel, Oaxaca, \\ México. \\ 4 Departamento de Hidrobiología, Universidad Autónoma Metropolitana, San Rafael Atlixco 186, \\ 09340 Distrito Federal, México.
}

* Corresponding author. E-mail: alopez@xanum.uam.mx

\begin{abstract}
The reproductive biology of the massive coral Pavona gigantea has been studied along Mexico's Pacific coast, but basic aspects such as its relation to local environmental variables and its variation on a mesoscale level have not been addressed. The reproductive cycle of P. gigantea was monitored monthly over a two-year period (2010-2012) at four sites along the coast of Oaxaca (southwestern Mexico). Except for one hermaphroditic colony, $P$. gigantea was gonochoric and exhibited asynchronous development. The data suggest that, in the study area, the species may reproduce seasonally, with minor interannual differences (May-September 2010, April-August 2011, April-May 2012). There were spatial and temporal variations in the percentage of reproductively active colonies and the presence of mature sex cells. A multiple regression analysis revealed that the percentage of reproductively active colonies was significantly explained (69.6\%) by mesoscale variations in environmental variables such as sea surface temperature, photosynthetically active radiation, diffuse attenuation coefficient, percentage of lunar illumination, and photoperiod, the latter being the most relevant variable in the model. The data suggest that temporal mesoscale variations can exert a meaningful influence on coral reproduction in the study area.
\end{abstract}

Key words: reproduction, gametogenesis, coral, spawning.

RESUMEN. La biología reproductiva del coral masivo Pavona gigantea en las aguas del Pacífico frente a las costas mexicanas ha sido estudiada; sin embargo, algunos aspectos básicos, como su relación con factores abióticos locales y su variación a nivel de mesoescala, no han sido resueltos. Se monitoreó el ciclo reproductivo de $P$. gigantea durante dos años (2010-2012) en cuatro localidades frente a la costa de Oaxaca, sudoeste de México, en el Pacífico. Pavona gigantea presentó colonias gonocóricas con desarrollo asincrónico y una colonia hermafrodita. Los datos sugieren que la especie podría reproducirse de manera estacional con variaciones interanuales (mayo-septiembre de 2010, abril-agosto de 2011, abril-mayo de 2012). Se observaron variaciones espaciotemporales en el porcentaje de colonias con actividad reproductiva y en la presencia de gametos maduros. El modelo de regresión lineal múltiple sugiere que las variaciones ambientales a mesoescala de temperatura superficial oceánica, radiación fotosintéticamente activa, coeficiente de atenuación difusa, porcentaje de iluminación lunar y fotoperiodo explicaron significativamente el 69.6\% de la variación en el porcentaje de colonias con actividad reproductiva, y el fotoperiodo fue la variable más importante en el modelo. Los datos indican que las variaciones temporales a mesoescala podrían influenciar la reproducción de las especies de coral en el área de estudio.

Palabras clave: reproducción, gametogénesis, coral, desove.

\section{INTRODUCTION}

Stony corals can reproduce asexually and sexually. In sexual reproduction, the gametes of both sexes exchange genetic material during fecundity and form a larva. Once competence has been attained, the larva settles and undergoes

\section{INTRODUCCIÓN}

Los corales pétreos son organismos con capacidad de reproducirse asexual y sexualmente. En la reproducción sexual, los gametos de ambos sexos intercambian material genético durante la fecundación y forman una larva. Una vez 
metamorphosis until a colony is formed. This process generally occurs annually (Harrison and Wallace 1990, Harrison 2011). This type of reproduction favors the dispersal of the species and maintains variation by the recombination of genetic material (Fadlallah 1983).

Coral reproduction involves processes such as gametogenesis and reproductive activity that are driven by environmental conditions (Harrison 2011). During periods of stress, some reproductive processes can be affected or inhibited, with the consequent reduction in fecundity or reproductive success (Harrison et al. 1984, Tanner 1996, Cortés 1997). Temperature is one of the main abiotic factors controlling the onset of the reproductive cycle, but photoperiod, wind and current patterns, lunar cycle, and irradiance can also act as cues to trigger and synchronize reproductive activity (Harrison 2011). Conversely, the reproductive cycle can be inhibited by extreme temperatures that exceed the thermotolerance of the species and by factors associated with light conditions, such as turbidity, sedimentation, and ultraviolet light.

The coral communities off the west coast of Mexico are considered among the most important of the Eastern Tropical Pacific (ETP). They have been described as small and patchy in distribution and can form sparse or dense assemblages (Glynn and Ault 2000, Glynn et al. 2000), composed mainly of species belonging to the genera Pocillopora ( $>90 \%$ coverage), Pavona ( $<5 \%$ coverage), and Porites ( $<1 \%$ coverage) (Glynn and Leyte-Morales 1997, Reyes-Bonilla and LópezPérez 1998, López-Pérez and Hernández-Ballesteros 2004).

Pavona gigantea Verrill, 1869 is a hermatypic coral endemic to the eastern Pacific (Glynn and Ault 2000), and it is one of the most common and widely distributed coral species off the west coast of Mexico (Reyes-Bonilla et al. 2005). The information available on the reproductive activity of this species is limited to reports for the equatorial Pacific Ocean and the Pacific coast of central and southern Mexico (Glynn et al. 1996, Carpizo-Ituarte et al. 2011, Rodríguez-Troncoso et al. 2011). Genetic studies (Saavedra-Soleto et al. 2011) suggest that the populations of $P$. gigantea along the west coast of Mexico are genetically isolated, which makes them vulnerable to local disturbances and extirpations and may even compromise the regional connectivity of the species. On a large scale, however, there is evidence that the southern populations can be relevant to the central populations and even to those that inhabit the Gulf of California (SaavedraSoleto et al. 2011).

The reproductive activity of stony corals can vary spatially depending on the local environmental conditions and the life history of the species (Somero 2005). In Central America, some species can develop gametes throughout the year and present microscale spatial variations (i.e., tens of meters) mainly associated with fluctuations in temperature and nutrients caused by upwelling (Glynn et al. 1996). In Pacific waters off southern and central Mexico, the onset of gametogenetic activity is directly related to the increase in alcanzado el estadio de competencia, la larva experimenta asentamiento y metamorfosis hasta desarrollar una colonia. Usualmente, estos procesos suceden en periodos anuales (Harrison y Wallace 1990, Harrison 2011). Este tipo de reproducción favorece la dispersión de la especie y garantiza la variabilidad mediante la recombinación del material genético (Fadlallah 1983).

El patrón reproductivo de una especie de coral incluye procesos como la gametogénesis y la actividad reproductiva, los cuales están determinados por las condiciones ambientales en donde se desarrolla la especie (Harrison 2011). Durante periodos de estrés, algunos procesos reproductivos pueden ser afectados o inhibidos y, consecuentemente, hay una reducción en la fecundidad o el éxito reproductivo (Harrison et al. 1984, Tanner 1996, Cortés 1997). La temperatura es uno de los principales factores abióticos que controlan el inicio del proceso reproductivo, pero el fotoperiodo, los patrones del viento o corrientes, los ciclos lunares y la irradianza también pueden actuar como señales para iniciar y sincronizar los ciclos reproductivos (Harrison 2011). Por el contrario, algunos factores que causan inhibición del proceso reproductivo son las temperaturas extremas que rebasan los límites de termotolerancia de la especie y los factores relacionados con la condición lumínica del área (i.e., turbidez, sedimentación, luz ultravioleta).

Las comunidades coralinas en las aguas del Pacífico frente a la costa occidental de México están descritas como algunas de las más importantes del Pacífico Oriental Tropical (POT). Se caracterizan por estar formadas por colonias pequeñas con distribución en parche y que pueden formar agregaciones densas o espaciadas (Glynn y Ault 2000, Glynn et al. 2000), construidas principalmente por especies pertenecientes a los géneros Pocillopora ( $>90 \%$ cobertura), Pavona $(<5 \%$ cobertura) y Porites $(<1 \%$ cobertura) (Glynn y LeyteMorales 1997, Reyes-Bonilla y López-Pérez 1998, LópezPérez y Hernández-Ballesteros 2004).

Pavona gigantea Verrill, 1869 es un coral hermatípico endémico del Pacífico oriental (Glynn y Ault 2000) y es de los más comunes y más ampliamente distribuidos frente a la costa occidental de México (Reyes-Bonilla et al. 2005). Existe limitada información sobre la actividad reproductiva de esta especie, ya que sólo se cuenta con algunos registros para el Pacífico ecuatorial y las costas occidentales del centro y sur de México (Glynn et al. 1996, Carpizo-Ituarte et al. 2011, Rodríguez-Troncoso et al. 2011). Estudios genéticos (Saavedra-Soleto et al. 2011) sugieren que las poblaciones de $P$. gigantea frente a la costa occidental de México se encuentran genéticamente aisladas, lo que las hace vulnerables a perturbaciones y extirpaciones locales y, en última instancia, compromete la conectividad regional de la especie. A gran escala, sin embargo, se ha comprobado que las poblaciones del sur pueden ser de relevancia para las poblaciones del centro y aun para aquellas que se desarrollan en el golfo de California (Saavedra-Soleto et al. 2011). 
sea surface temperature (SST) during summer (CarpizoItuarte et al. 2011, Rodríguez-Troncoso et al. 2011); however, to date, there are no reports of the presence of mature gametes or any evidence of spawning and there is a lack of information regarding the mesoscale variations in reproduction in the region.

Information on reproductive success (i.e., from gamete formation and release to larval settlement) is essential for a better understanding of the development, permanence, and recovery of coral reefs and communities after natural or anthropogenic disurbances in the region. This paper contributes information on the reproductive cycle of $P$. gigantea off the coast of Oaxaca (southwestern Mexico), analyzes the spatial and temporal variations, and evaluates whether the reproductive activity is influenced by environmental variations in the area.

\section{MATERIALS AND Methods}

\section{Study area}

Samples were collected from Montosa Island and three beaches (Estacahuite, Riscalillo, and La Entrega) along the coast of Oaxaca, located in the coastal corridor known as Mazunte-Bahías de Huatulco $\left(15^{\circ} 39^{\prime} \mathrm{N}, 9^{\circ} 33^{\prime} \mathrm{W} ; 15^{\circ} 45^{\prime} \mathrm{N}\right.$, $96^{\circ} 04^{\prime} \mathrm{W}$ ) (fig. 1). The maximum distance between sampling sites is $45 \mathrm{~km}$; however, despite their proximity, the four sites have different characteristics and dimensions: at La Entrega, the reef covers an area of 3.51 ha and has a maximum depth of $13.3 \mathrm{~m}$; at Riscalillo, the reef covers an area of 3.51 ha and has a maximum depth of $10 \mathrm{~m}$; at Estacahuite, the reef covers an area of 2.30 ha and has a maximum depth of $20 \mathrm{~m}$ (LópezLópez 2011); and at Montosa Island, the reef covers an area

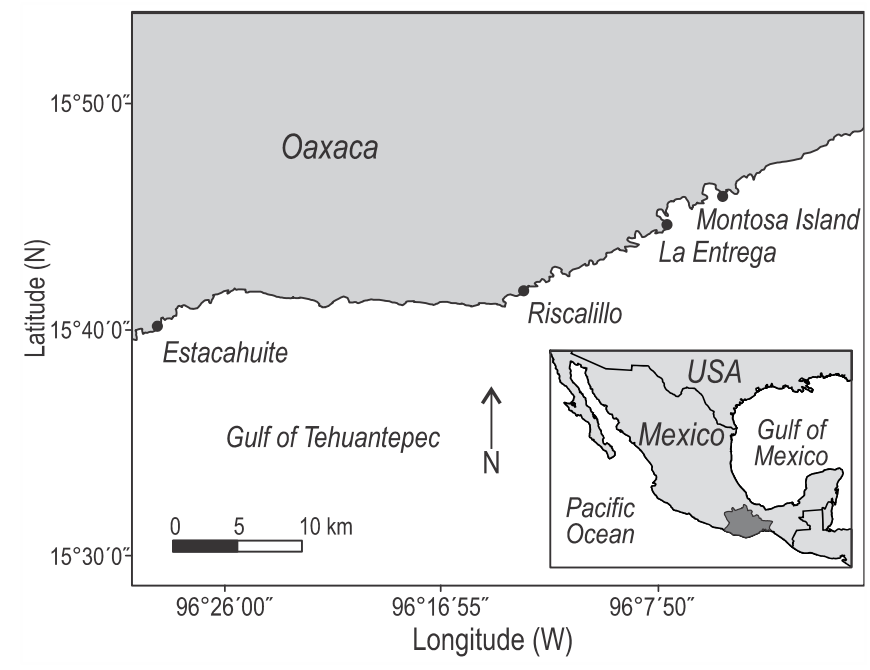

Figure 1. Location of sampling stations along the coast of Oaxaca, southwestern Mexico.

Figura 1. Ubicación geográfica de los sitios de muestreo a lo largo de la costa de Oaxaca, México.
La actividad reproductiva de los corales pétreos puede presentar diferencias espaciales debidas a las condiciones ambientales locales y a la historia de vida de la especie (Somero 2005). Registros en Centroamérica muestran que algunas especies pueden desarrollar gametos durante todo el año y presentar variaciones espaciales a microescala (i.e., decenas de metros) asociadas, principalmente, a fluctuaciones de temperatura y nutrientes ocasionadas por surgencias (Glynn et al. 1996). En las aguas del Pacífico frente a la parte central y sur de México, el inicio de la actividad gametogénica está directamente asociada al incremento de la temperatura superficial del mar (TSM) durante el verano (Carpizo-Ituarte et al. 2011, Rodríguez-Troncoso et al. 2011); sin embargo, hasta la fecha no se ha reportado la presencia de gametos maduros o alguna evidencia de desove y se carece de información respecto a las variaciones reproductivas a nivel de mesoescala en la región.

La información respecto al éxito reproductivo, considerado desde la formación y liberación de gametos hasta el asentamiento larval, es esencial para el entendimiento del desarrollo, permanencia y recuperación de las comunidades y arrecifes coralinos de la región luego de perturbaciones naturales o antropogénicas. En este sentido, la presente contribución aporta información respecto al ciclo reproductivo de $P$. gigantea frente a la costa occidental de Oaxaca (México), analiza sus variaciones espaciotemporales y evalúa si la reproducción está influenciada por las variaciones ambientales en el área.

\section{MATERIALES Y MÉTOdo}

\section{Área de estudio}

La recolecta de muestras se realizó en las playas Estacahuite, Riscalillo y La Entrega y frente a isla Montosa, ubicadas en el corredor costero denominado Mazunte-Bahías de Huatulco $\left(15^{\circ} 39^{\prime} \mathrm{N}, 96^{\circ} 33^{\prime} \mathrm{W} ; 15^{\circ} 45^{\prime} \mathrm{N}, 9^{\circ} 04^{\prime} \mathrm{W}\right)$ frente a la costa de Oaxaca (fig. 1). A pesar de su cercanía entre sí, los cuatro sitios poseen características y dimensiones distintas. La Entrega tiene una superficie arrecifal de 3.51 ha con profundidad máxima de $13.3 \mathrm{~m}$; Riscalillo, una superficie arrecifal de 3.51 ha con profundidad máxima de $10 \mathrm{~m}$; Estacahuite, una superficie arrecifal de 2.30 ha con profundidad máxima de 20 m (López-López 2011); e isla Montosa, superficie arrecifal de 11.8 ha con profundidad máxima de 11.6 m (Glynn y Leyte-Morales 1997). La distancia máxima entre los sitios de muestreo es de $45 \mathrm{~km}$.

El clima de la región es de tipo cálido subhúmedo, con precipitación menor que el 5\% del porcentaje anual durante el verano (García 1973). Las localidades de muestreo forman parte de la zona de influencia del golfo de Tehuantepec. En el área de estudio se presentan escasas descargas de ríos, sedimentos arenosos y surgencias estacionales que producen valores bajos de temperatura y oxígeno disuelto y altas concentraciones de nutrimentos (Tapia-García et al. 2007). 
of 11.8 ha and has a maximum depth of $11.6 \mathrm{~m}$ (Glynn and Leyte-Morales 1997).

The region has a warm subhumid climate, and summer rains account for less than $5 \%$ of the annual precipitation (García 1973). The sampling sites are within the Gulf of Tehuantepec, characterized by scant river inputs, sandy sediments, and seasonal upwelling that is responsible for low temperature and dissolved oxygen values and high nutrient concentrations (Tapia-García et al. 2007). During winter and spring, northerly wind events known as Tehuanos occur in the region. These winds are produced when there is a difference in atmospheric pressure between the Gulf of Mexico and the tropical Pacific (Steenburgh et al. 1998). They generate mesoscale eddies in the Gulf of Tehuantepec that can affect tens of kilometers and cause a decrease in SST, which promotes the formation of a shallow thermocline and generates thermal anomalies and changes in the concentration of chlorophyll (Kessler 2002, Fernández-Álamo and Farber-Lorda 2006).

\section{Survey}

Monthly surveys were conducted from May 2010 to May 2012. At each site, fragments of approximately $3 \mathrm{~cm}^{2}$ were collected from five randomly selected colonies of $P$. gigantea by scuba divers. The selected colonies measured more than $30 \mathrm{~cm}$ in diameter and did not show signs of bleaching. The fragments were fixed in situ in $10 \%$ formaldehyde in seawater for $24 \mathrm{~h}$, and then transferred to $70 \%$ ethyl alcohol and stored at room temperature until processing. Each fragment was decalcified individually in a solution of $10 \%$ acetic acid for $24 \mathrm{~h}$. The tissue was dehydrated in an eight-stage ethyl alcohol series $(70 \%, 80 \%, 90 \%, 90 \%, 96 \%, 96 \%, 100 \%$, and $100 \%$ ) and a two-step whitening treatment with Citrisol in a Leica TP102 automatic tissue processor. The tissues were embedded in Paraplast in a Leica EG1160 tissue embedding center, and $6-\mu \mathrm{m}$-thick sections were cut with a Leica RM2145 semiautomatic microtome. The sections were immediately stained with hematoxylin and eosin and then mounted with synthetic resin. The coral tissue was examined under a Carl Zeiss AxioScope optical miscroscope and photo-documented using a AxioCam ERc 5s digital camera. The maximum diameter of oocytes was measured using AxioVision Rel v2.0 for Windows. The reproductive stages were determined according to the criteria proposed by Glynn et al. (1996), Carpizo-Ituarte et al. (2011) and RodríguezTroncoso et al. (2011).

\section{Environmental variables}

At each site, SST was measured in situ using a Hanna HI9828 multiparameter meter (accuracy $\pm 0.15^{\circ} \mathrm{C}$ ). The diffuse attenuation coefficient (Kd490) and photosynthetically active radiation (PAR) were derived from satellite images (Aqua/MODIS, http://oceancolor.gsfc.nasa.gov).
En el golfo de Tehuantepec, durante el invierno y la primavera, se presentan vientos del norte, denominados tehuanos, en dirección perpendicular a la costa; estos vientos se producen por una diferencia de presión atmosférica entre el golfo de México y el Pacífico tropical (Steenburgh et al. 1998). Los vientos tehuanos generan remolinos de mesoescala que pueden afectar hasta decenas de kilómetros y producir un decremento en la TSM, lo cual promueve la formación de una termoclina somera y genera anomalías térmicas y cambios en la concentración de clorofila (Kessler 2002, Fernández-Álamo y Farber-Lorda 2006).

\section{Muestreo}

Se realizaron muestreos mensuales de mayo de 2010 a mayo de 2012. En cada localidad se recolectaron, mediante buceo autónomo, fragmentos de aproximadamente $3 \mathrm{~cm}^{2}$ de cinco colonias de $P$. gigantea elegidas al azar. Las colonias seleccionadas midieron más de $30 \mathrm{~cm}$ de diámetro y no presentaron signos de blanqueamiento. Los fragmentos fueron fijados in situ con formaldehido al $10 \%$ en agua de mar durante $24 \mathrm{~h}$, y luego se conservaron en alcohol etílico al $70 \%$ a temperatura ambiente hasta su procesamiento. Cada fragmento se descalcificó individualmente en una solución de ácido acético al $10 \%$ durante $24 \mathrm{~h}$. El tejido fue deshidratado en un tren de ocho pasos con alcohol etílico $(70 \%, 80 \%$, $90 \%, 90 \%, 96 \%, 96 \%, 100 \%$ y $100 \%$ ) y dos pasos de aclarado con Citrisol en el procesador automático de tejidos Leica TP102. Los tejidos fueron incluidos en Paraplast en el incluidor de tejidos Leica EG1160. Se realizaron cortes de $6 \mu \mathrm{m}$ de grosor con un micrótomo semiautomático Leica RM2145. Las laminillas fueron teñidas mediante la técnica hematoxilina-eosina y montadas con resina sintética. Las observaciones del tejido coralino se realizaron en un microscopio óptico Carl Zeiss AxioScope, y se foto-documentaron mediante una cámara digital AxioCam ERc 5s. Se midieron los ovocitos mediante el programa AxioVisionRel v2.0 para Windows, y se obtuvo el diámetro máximo de las células. Para delimitar los estadios de reproducción, se utilizaron los criterios de Glynn et al. (1996), Carpizo-Ituarte et al. (2011) y Rodríguez-Troncoso et al. (2011).

\section{Variables ambientales}

Se midió la TSM in situ en cada localidad mediante una sonda multiparamétrica Hanna HI9828 (precisión $\pm 0.15^{\circ} \mathrm{C}$ ). Los valores del coeficiente de atenuación difusa $(\mathrm{Kd} 490)$ y de la radiación fotosintéticamente disponible (PAR, por sus siglas en inglés) fueron extraídos de imágenes de satélite (Aqua-MODIS, http://oceancolor.gsfc.nasa.gov). Debido a que, por factores meteorológicos, los datos para los días de muestreo no estaban disponibles, las imágenes utilizadas para la extracción de datos son resultado del promedio de ocho días antes de la fecha de cada muestreo. Las imágenes AquaModis (nivel 3 de procesamiento, resolución de $9 \times 9 \mathrm{~km}$ ) 
Owing to meteorological factors, the data for our sampling days were unavailable, so the images used to extract the data represent the average of the eight days prior to each survey. The Aqua/MODIS images (level 3 processing, resolution of $9 \times 9 \mathrm{~km}$ ) were processed using the Wam_statist program. Lunar illumination (\%) and photoperiod data (resolution of $1 \times 1 \mathrm{~km}$ ) were obtained from the Weather Underground database (http://www.wunderground.com/) for each sampling day.

\section{Data analysis}

We determined the sex ratio and the percentage of reproductively active male and female colonies. The data for all the environmental variables and the percentage of reproductively active colonies were subjected to tests for normality (Kolmogorov-Smirnov, $P<0.05$ ) and homogeneity of variance. As the data were neither normally distributed nor homoscedastic, a nonparametric analysis of variance (Kruskal-Wallis) was performed to determine possible differences between sites. Since there were no significant differences in regard to the environmental variables (SST, $H_{(3,68)}=0.265, P=0.966$; PAR, $H_{(3,68)}=0.307, P=0.959$; $\left.\mathrm{Kd} 490, H_{(3,68)}=2.499, P=0.475\right)$, the data were averaged to obtain a monthly value for the study area. The relation between the averages of the environmental variables and the percentage of reproductively active male and female colonies was assessed by multiple linear regression analysis in order to examine whether the reproductive activity of $P$. gigantea was related to environmental conditions in the area and to determine the most important variable(s) in the reproductive process. The statistical analyses were performed using Statistica v.6.

\section{RESULTS}

\section{Reproduction}

Pavona gigantea had three reproductive periods during the study: May-September 2010, April-August 2011, and April-May 2012. All the colonies were gonochoric (fig. 2a) except for one, which was hermaphroditic (fig. 2b). The species displayed asynchronous maturation and the sex ratio was 1:1.5 (male:female).

The cord-like female germ cells extended from the mesentery to the gastric cavity of the polyp. Four stages of oocyte maturation were observed (fig. 3). Stage I oocytes (5-30 $\mu \mathrm{m}$ in diameter) were observed in May 2010; they were oval in shape and the nucleus occupied most of the cytoplasm (fig. 3a). Stage II oocytes (31-50 $\mu \mathrm{m}$ in diameter) were observed in May and June 2010 and presented a welldefined nucleus and nucleolus, as well as a cord-like arrangement of previtellogenic oocytes (fig. 3b). Stage III oocytes (51-100 $\mu \mathrm{m}$ in diameter) occurred throughout the reproductive cycle; they were partially vitellogenic and presented a nucleus, nucleolus, and lipid vacuoles, as well as symbionts fueron procesadas mediante el programa Wam_statist. Los datos de iluminación lunar (\%) y fotoperiodo fueron extraídos de la base de datos Weather Underground (http:// www.wunderground.com/, resolución de 1x1 km) para cada día de muestreo.

\section{Análisis de datos}

Se obtuvo la proporción de sexos y el porcentaje de colonias con actividad reproductiva para ambos sexos. Los datos de cada una de las variables ambientales y el porcentaje de colonias con actividad reproductiva se analizaron mediante pruebas de normalidad (Kolmogorov-Smirnov, $P<0.05$ ) y homogeneidad de varianza. Debido a que los datos no fueron normales ni homocedásticos, se realizó un análisis de varianza no paramétrico de Kruskal-Wallis para evaluar posibles diferencias entre localidades. Debido a que no se detectaron diferencias significativas entre localidades respecto a las variables ambientales (TSM, $H_{(3,68)}=0.265, P=0.966$; PAR, $H_{(3,68)}=0.307, P=0.959 ; \mathrm{Kd} 490, H_{(3,68)}=2.499, P=$ $0.475)$, los datos se promediaron para obtener un valor mensual para el área de estudio. La relación entre los promedios de las variables ambientales y el porcentaje de colonias con actividad reproductiva de hembras y machos se evaluó mediante un análisis de regresión lineal múltiple con el fin de detectar si la actividad reproductiva de $P$. gigantea estaba relacionada con las condiciones ambientales del área y determinar la o las variables más importantes en el proceso reproductivo de la especie. Los análisis estadísticos fueron realizados con el programa Statistica v.6.

\section{RESUltados}

\section{Reproducción}

Pavona gigantea presentó tres periodos reproductivos durante el estudio: mayo-septiembre de 2010, abril-agosto de 2011 y abril-mayo de 2012. La especie mostró un comportamiento reproductivo gonocórico en la mayoría de las colonias (fig. 2a) y hermafroditismo en una sola colonia (fig. 2b). La maduración fue de tipo asincrónica y la proporción de sexos fue de 1:1.5 (macho:hembra).

Respecto al desarrollo, las células germinales femeninas presentaron un arreglo en forma de cordones que se extendió del mesenterio hacia la cavidad gástrica del pólipo. Se observaron cuatro estadios de maduración de ovocitos (fig. 3). Los ovocitos en estadio I (5-30 $\mu \mathrm{m}$ de diámetro) se observaron durante mayo de 2010; presentaron una forma ovalada y el núcleo abarcó la mayor parte del citoplasma de la célula (fig. 3a). Los ovocitos en estadio II (31-50 $\mu \mathrm{m}$ de diámetro) se observaron en mayo y junio de 2010 y presentaron un núcleo y nucléolo bien definidos, además de empaquetamiento de los ovocitos previtelogénicos en forma de cordones (fig. 3b). Los ovocitos en estadio III (51-100 $\mu \mathrm{m}$ de diámetro) se presentaron durante toda la 

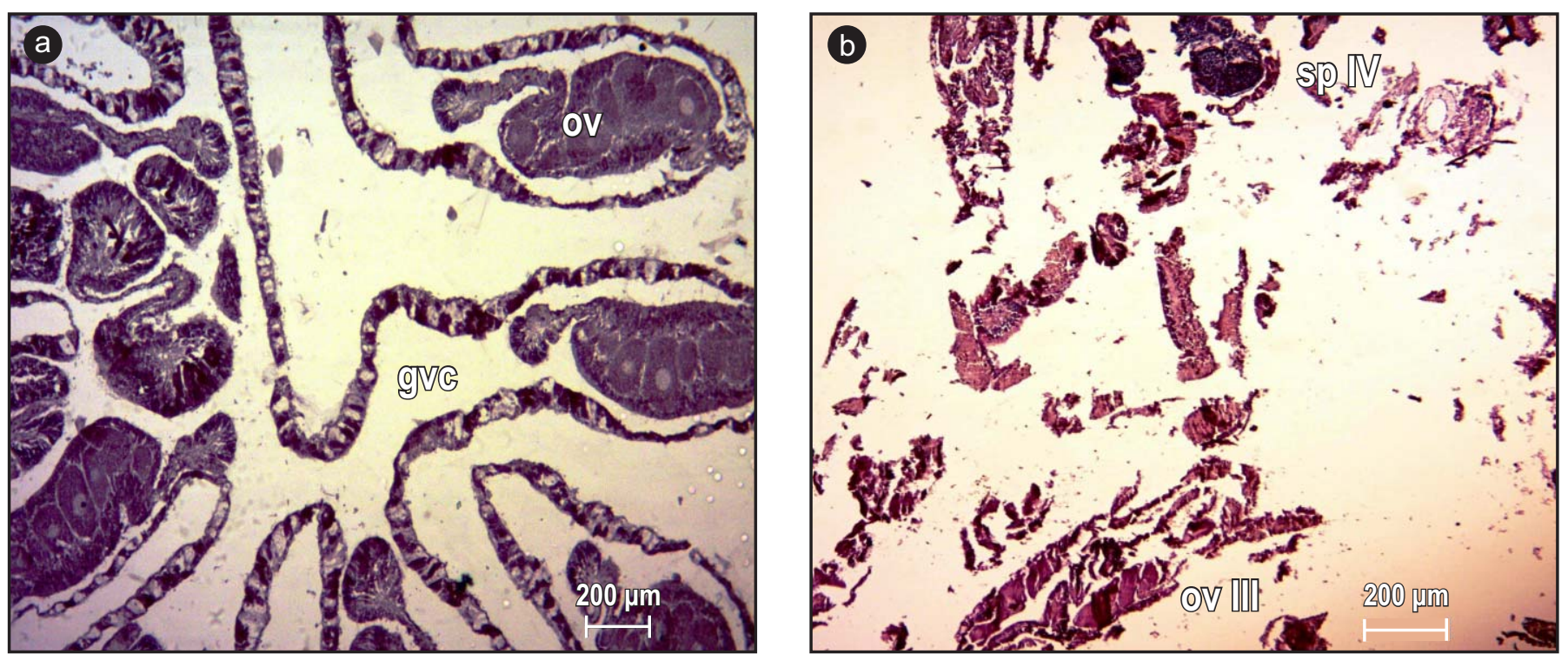

Figure 2. Reproductive activity of Pavona gigantea off the coast of Oaxaca (southwestern Mexico). (a) Entire gonochoric polyp (4×) and (b) hermaphroditic polyp (4×). Abbreviations: sp IV, stage IV spermaries; gvc, gastrovascular cavity; ov III, stage III oocyte.

Figura 2. Actividad reproductiva de Pavona gigantea frente a la costa de Oaxaca (sudoeste de México). (a) Pólipo gonocórico completo (4×) y (b) pólipo hermafrodita $(4 \times)$. Abreviaciones: sp IV, espermiarios en estadio IV; gvc, cavidad gastrovascular; ov III, ovocito en estadio III.

at the periphery of the cell (fig. 3c). Stage IV oocytes $(>100 \mu \mathrm{m}$ in diameter) were observed in June 2010 and August 2011; they were considered mature gametes and were characterized by the migration and reduction of the nucleus, located on the opposite side of the cytoplasm (fig. 3d).

Spermaries were found in sacs that extended from the mesentery to the gastric cavity. Mature cells were observed in $85.7 \%$ of the male colonies. Stage II spermatocytes were observed only in June 2011 and 2012, and presented prominent nuclei that migrated from the periphery of the sac and formed clusters (fig. 3e). During stage IV, the spermatids were clearly reduced in size as a result of the elimination of the cytoplasm during spermiogenesis, and the clusters migrated towards the periphery of the spermaries, where flagella aligned towards the central region were observed (fig. 3f).

The Riscalillo colonies exhibited the highest reproductive activity $(13.63 \%, n=85)$ and a sex ratio of $1: 3(\mathrm{M}: \mathrm{F})$, whereas the La Entrega colonies exhibited the lowest reproductive activity $(7.78 \%, n=90)$ and a sex ratio of $1: 0.75$ (M:F). The colonies from Estacahuite and Montosa Island were characterized by the presence of mature oocytes and spermaries in August 2011 (table 1). Nonetheless, the analysis of variance indicated that there were no significant differences in the reproductive activity of $P$. gigantea between sites $\left(H_{(3,68)}=4.029, P=0.2583\right)$.

\section{Temporal variation in reproductive activity}

During the three reproductive periods recorded in this study, more than $20 \%$ of the $P$. gigantea colonies presented época reproductiva, estaban parcialmente vitelados y presentaron núcleo, nucléolo y vacuolas lipídicas, así como simbiontes en la periferia de la célula (fig. 3c). Los ovocitos en estadio IV ( $>100 \mu \mathrm{m}$ de diámetro) se observaron solamente en junio de 2010 y agosto de 2011; se consideraron gametos maduros y se caracterizaron por la migración y reducción del núcleo, que se encontró del lado opuesto al citoplasma (fig. 3d).

Por otra parte, los espermiarios se observaron contenidos en sacos que se originaron del mesenterio y se extendieron hacia la cavidad gástrica. El $85.7 \%$ de las colonias masculinas presentaron células maduras. Los espermatocitos en estadio II se observaron solamente en junio de 2011 y mayo de 2012, y presentaron núcleos prominentes que iniciaban la migración a la periferia del saco para formar empaquetamientos (fig. 3e). Durante el estadio IV se observaron espermátidas, claramente reducidas en tamaño como producto de la eliminación del citoplasma durante la espermiogénesis; además, se observó la migración de los racimos hacia la periferia del espermiario, donde fue posible observar los flagelos alineados hacia la región central (fig. 3f).

Las colonias recolectadas en Riscalillo presentaron la mayor actividad reproductiva $(13.63 \%, n=85)$ y una proporción de sexos de 1:3 (M:H), mientras que aquellas muestreadas en La Entrega presentaron la menor actividad reproductiva $(7.78 \%, n=90)$ y una proporción de sexos de 1:0.75 (M:H). Las colonias recolectadas en Estacahuite e isla Montosa se caracterizaron por la presencia de ovocitos y espermiarios maduros durante agosto de 2011 (tabla 1). No obstante lo anterior, el analisis de varianza evidencio que no 


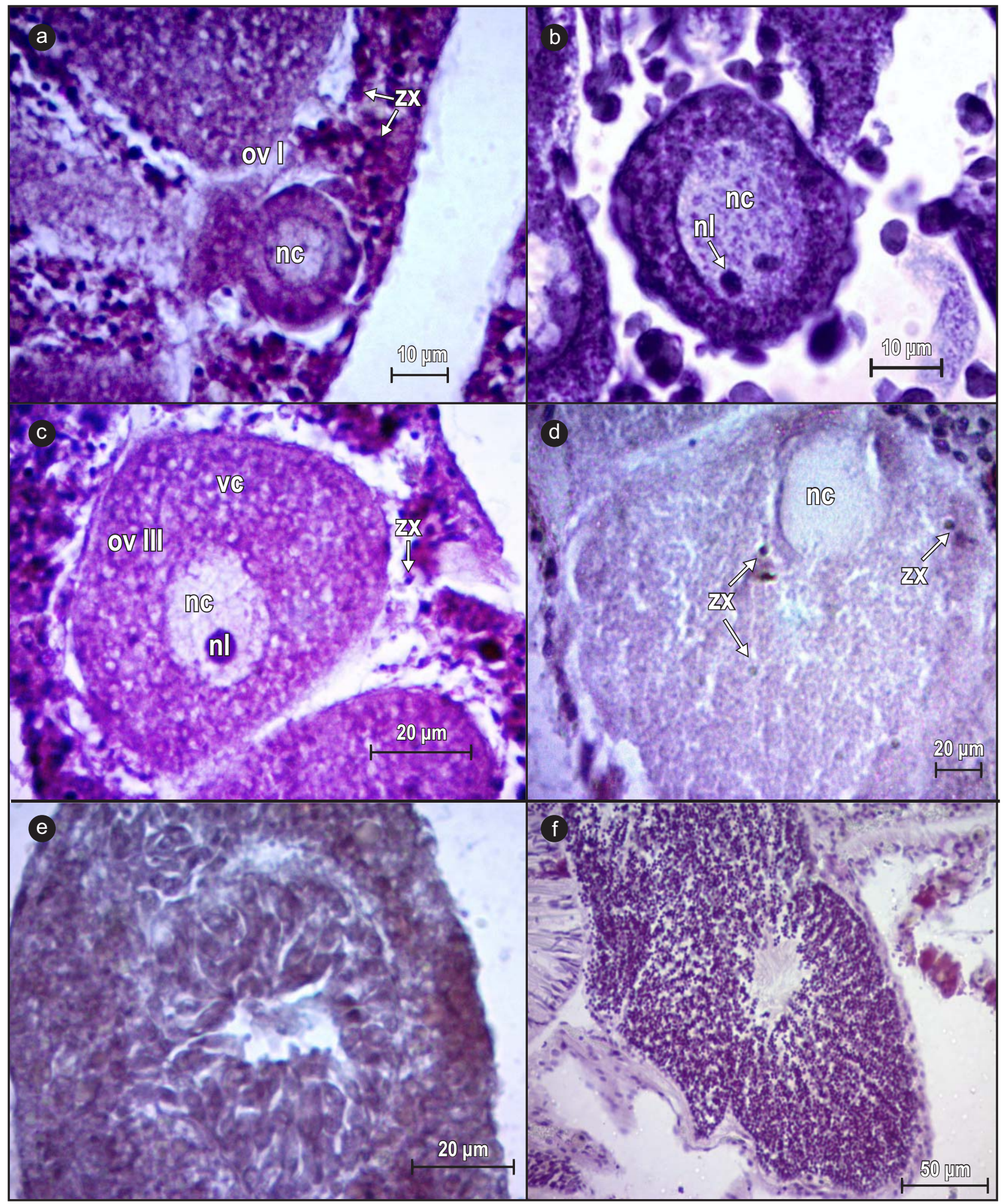

Figure 3. Developmental stages of Pavona gigantea reproductive cells off the coast of Oaxaca (southwestern Mexico). (a) Stage I oocyte (ov I), (b) stage II oocyte, (c) stage III oocyte (ov III), (d) stage IV oocyte, (e) stage II spermaries, and (f) stage IV spermaries (100×). Abbreviations: zx, symbiont; nc, nucleus; nl, nucleolus; vc, vacuoles.

Figura 3. Estadios de desarrollo de células reproductivas de Pavona gigantea frente a la costa de Oaxaca, (sudoeste de México). (a) Ovocito estadio I (ov I), (b) ovocito en estadio II, (c) ovocito en estadio III (ov III), (d) ovocito en estadio IV, (e) espermiarios en estadio II, y (f) espermiarios en estadio IV (100×). Abreviaciones: zx, simbionte; nc, núcleo; nl, nucléolo; vc, vacuolas. 
Table 1. Presence of male and female sex cells and developmental stages (Roman numerals) in Pavona gigantea samples collected at four sites along the coast of Oaxaca (Mexico) between May 2010 and May 2012. The grey boxes indicate the presence of both mature male and female gametes in the same place at the same time.

Tabla 1. Presencia de células sexuales femeninas y masculinas y estadios de desarrollo (números romanos) en las muestras de Pavona gigantea recolectadas en cuatro localidades frente a la costa de Oaxaca (México) de mayo de 2010 a mayo de 2012. Los recuadros grises marcan la presencia de células maduras masculinas y femeninas en el mismo espacio y al mismo tiempo.

\begin{tabular}{|c|c|c|c|c|c|c|c|c|c|c|c|c|c|c|c|c|}
\hline Month & \multicolumn{4}{|c|}{ Estacahuite } & \multicolumn{4}{|c|}{ Riscalillo } & \multicolumn{4}{|c|}{ La Entrega } & \multicolumn{4}{|c|}{ Montosa Island } \\
\hline May 2010 & & & & & & & q & & & & & & q & q & q & \\
\hline Jun 2010 & & $q$ & q & q & & q & & & & o & $q$ & $\hat{\sigma}$ & & & & $\hat{\sigma}$ \\
\hline Aug 2010 & & & & & & & q & & & & & & & & & \\
\hline Sep 2010 & & & & & & & & & & & & & & & & $\hat{\sigma}$ \\
\hline Dec 2010 & & & & & & & & & & & & & & & & \\
\hline Jan 2011 & & & & & & & & & & & & & & & & \\
\hline Mar 2011 & & & & & & & & & & & & & & & & \\
\hline Apr 2011 & & & & & & & & & & & & $\hat{0}$ & & & & \\
\hline Sep 2011 & & & & & & & & & & & & & & & & \\
\hline Oct 2011 & & & & & & & & & & & & & & & & \\
\hline Dec 2011 & & & & & & & & & & & & & & & & \\
\hline Feb 2012 & & & & & & & & & & & & & & & & \\
\hline Apr 2012 & & & & & & & ㅇ & & & & & & & & & \\
\hline May 2012 & & & & & & & 우 & $\lambda$ & & & & & & $\hat{0}$ & o & \\
\hline
\end{tabular}

reproductive activity (June 2010, August 2011, and May 2012). Peak reproductive activity occurred in June 2010 and there were periods of inactivity between the reproductive periods.

Reproductive activity occurred when SST was between 28 and $31^{\circ} \mathrm{C}$ (fig. 4), PAR exceeded $48 \mathrm{~mol}$ photons $\mathrm{m}^{-2}$ day (fig. 5), Kd490 was less than $0.1490 \mathrm{~nm} \mathrm{~m}^{-1}$ (fig. 6), and the photoperiod was longer than $12 \mathrm{~h}$ (fig. 7). There was no relation between the percentage of lunar illumination on the day of sampling and reproductive activity (fig. 8); however, the months when mature oocytes were observed (June 2010 and August 2011) coincided with high percentages of illumination.

The multiple linear regression model explained $69.6 \%$ of the variation in the percentage of reproductively active colonies when both sexes were considered $(R=0.834, n=18$, $P=0.007), 67 \%$ when only females were considered $(R=$ $0.818, n=18, P=0.012$ ), and $51 \%$ when only males were considered $(R=0.714, n=18, P=0.09)$. Hence, the model adequately explained the variation in the reproductive activity of $P$. gigantea when both sexes or only females were considered in the analysis, but was not adequate when only existieron diferencias significativas en la actividad reproductiva de $P$. gigantea entre sitios $\left(H_{(3,68)}=4.029, P=0.2583\right)$.

\section{Variación temporal de la actividad reproductiva}

Durante los tres periodos reproductivos registrados en el estudio, más del $20 \%$ de las colonias de P. gigantea presentaron actividad reproductiva (junio de 2010, agosto de 2011, mayo de 2012). El pico reproductivo durante el periodo de estudio ocurrió en junio de 2010 y se observaron lapsos de inactividad entre épocas reproductivas.

La actividad reproductiva se observó cuando la TSM fue de entre 28 y $31^{\circ} \mathrm{C}$ (fig. 4), la PAR fue mayor que $48 \mathrm{~mol}$ fotones $\mathrm{m}^{-2}$ día (fig. 5), $\mathrm{Kd} 490$ fue menor que $0.1490 \mathrm{~nm} \mathrm{~m}^{-1}$ (fig. 6) y el fotoperiodo duró más de 12 h (fig. 7). Por el contrario, el porcentaje de iluminación lunar del día de muestreo no mostró relación con la actividad reproductiva (fig. 8); sin embargo, los meses en los cuales se observaron ovocitos maduros (junio de 2010, agosto de 2011) coincidieron con los altos porcentajes de iluminación lunar.

El modelo de regresión lineal múltiple explicó el 69.6\% de la variación en el porcentaje de colonias con actividad 


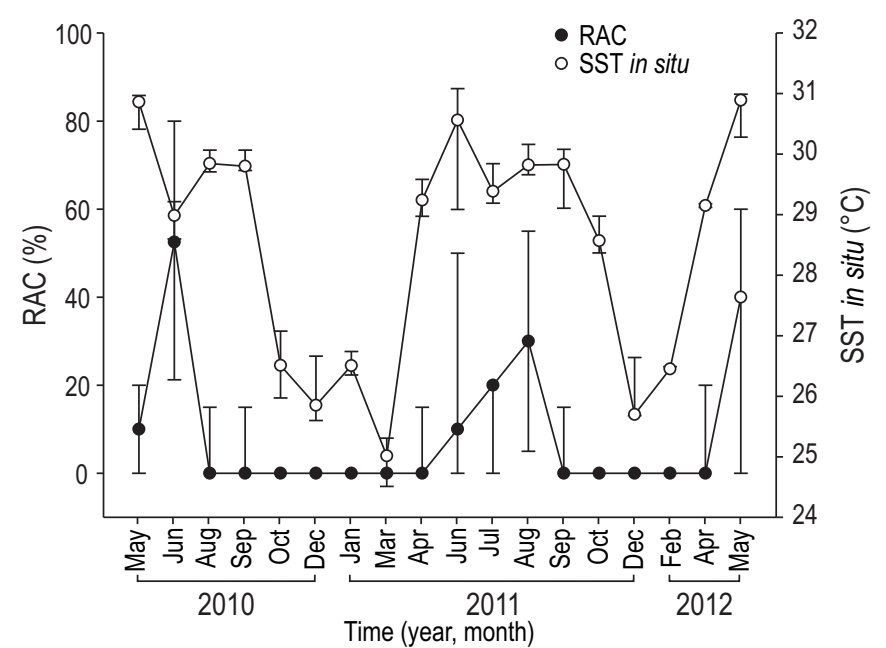

Figure 4. Relationship between in situ sea surface temperature (SST) and the percentage of reproductively active colonies (RAC) of Pavona gigantea (median and standard deviation) off the coast of Oaxaca (southwestern Mexico).

Figura 4. Relación de la temperatura (SST) in situ con el porcentaje de colonias de Pavona gigantea con actividad reproductiva (RAC) (mediana y desviación estándar) frente a la costa de Oaxaca (sudoeste de México).

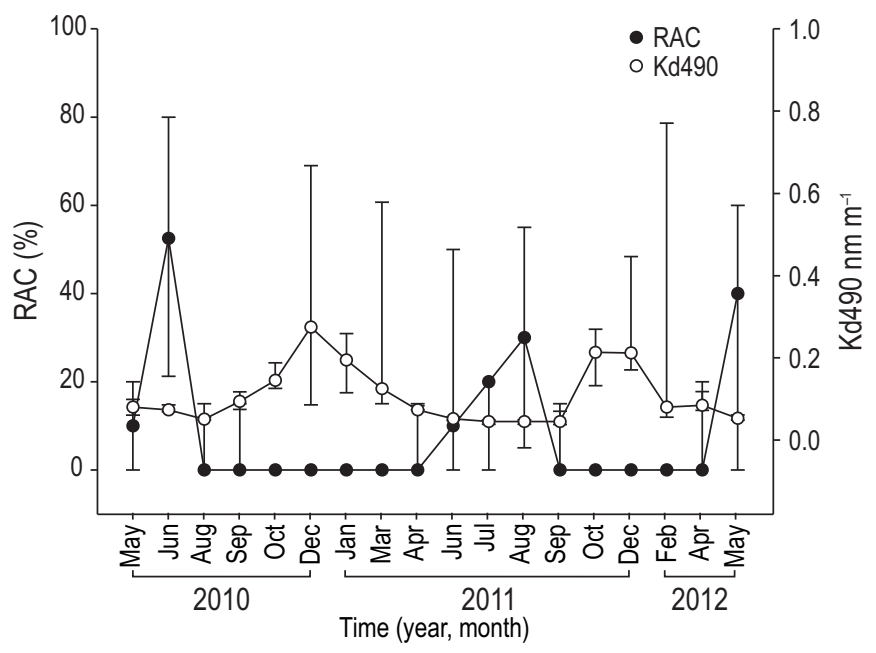

Figure 6. Relationship between the diffuse attenuation coefficient $(\mathrm{Kd} 490)$ and the percentage of reproductively active colonies (RAC) of Pavona gigantea (median and quartiles) off the coast of Oaxaca (southwestern Mexico).

Figura 6. Relación del coeficiente de atenuación difusa (Kd490) con el porcentaje de colonias de Pavona gigantea con actividad reproductiva (RAC) (mediana y cuartiles) frente a la costa de Oaxaca (sudoeste de México).

males were considered. This indicates that oocyte development of this coral species is significantly influenced by changes in the environmental conditions of this region. The analysis revealed that the percentage of reproductively active colonies was highly correlated with photoperiod $(R=0.739)$,

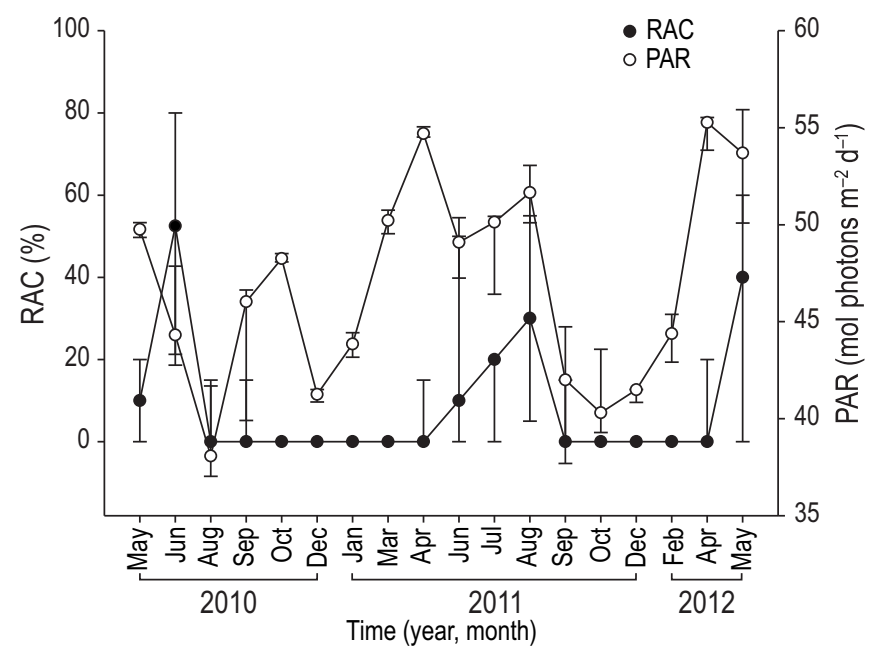

Figure 5. Relationship between photosynthetically active radiation (PAR) and the percentage of reproductively active colonies (RAC) of Pavona gigantea (median and quartiles) off the coast of Oaxaca (southwestern Mexico).

Figura 5. Relación de la radiación fotosintéticamente disponible (PAR) con el porcentaje de colonias de Pavona gigantea con actividad reproductiva (RAC) (mediana y cuartiles) frente a la costa de Oaxaca (sudoeste de México).

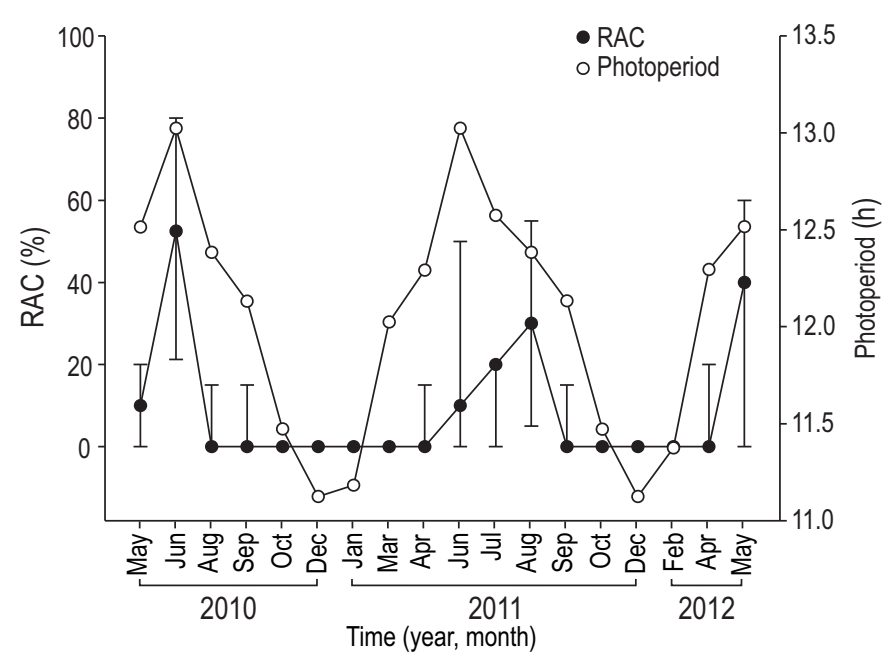

Figure 7. Relationship between photoperiod and the percentage of reproductively active colonies (RAC) of Pavona gigantea (median and standard deviation) off the coast of Oaxaca (southwestern Mexico).

Figura 7. Relación del fotoperiodo con el porcentaje de colonias de Pavona gigantea con actividad reproductiva (RAC) (mediana y desviación estándar) frente a la costa de Oaxaca (sudoeste de México).

reproductiva cuando se consideraron ambos sexos $(R=$ $0.834, n=18, P=0.007)$, el $67 \%$ cuando solo las hembras fueron consideradas $(R=0.818, n=18, P=0.012)$ y el $51 \%$ cuando solo los machos fueron considerados $(R=0.714, n=$ $18, P=0.09)$. Así, el modelo fue significativo para explicar 


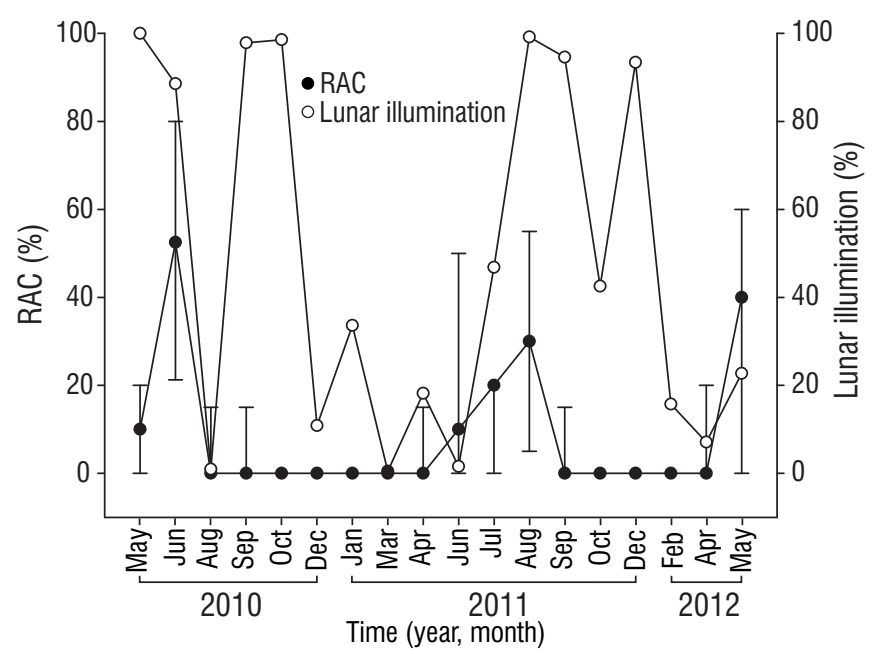

Figure 8. Relationship between the percentage of lunar illumination and the percentage of reproductively active colonies (RAC) of Pavona gigantea (median and standard deviation) off the coast of Oaxaca (southwestern Mexico).

Figura 8. Relación del porcentaje de iluminación lunar con el porcentaje de colonias con actividad reproductiva (RAC) (mediana y desviación estándar) frente a la costa de Oaxaca (sudoeste de México).

and was inversely related to $\mathrm{Kd} 490(R=-0.548), \mathrm{SST}(R=$ $0.49)$, PAR $(R=0.324)$, and percentage of lunar illumination $(R=0.056)$. This suggests that, in the study area, the reproductive pattern of $P$. gigantea is mainly related to the length of the photoperiod and to a lesser extent to lunar illumination (table 2).

\section{DISCUSSION}

In the study area, the $P$. gigantea colonies were gonochoric. Only one hermaphroditic colony was found at Estacahuite in July 2011. This type of reproductive behavior, known as sequential cosexuality, has been reported for the study area and other areas of the ETP (Glynn et al. 1996, Rodríguez-Troncoso et al. 2011). Corals can begin their reproductive life as males and then become hermaphroditic and generate protandrous hermaphrodite colonies (Fadlallah 1983, Harrison 2011). It has been suggested that sequential cosexuality can guarantee sexual reproduction and increase connectivity among populations (Fadlallah 1983, Harrison and Wallace 1990), but it can also decrease genetic variability and increase the probablity of local or regional extinction of the species in question. In view of the small number of hermaphrodyte samples in the present and previous studies, it has not been possible to accurately determine whether P. gigantea is capable of developing sequential cosexuality and more studies are needed.

In our study area, P. gigantea displayed asynchronous maturation. This concurs with that reported for the southwestern coast of Mexico (Rodríguez-Troncoso et al. 2011), la variabilidad en la actividad reproductiva de P. gigantea cuando ambos sexos o solo las hembras fueron incluidos en el ánalisis, pero no significativo cuando solo los machos fueron incluidos; es decir, existen indicios para sugerir que el desarrollo de ovocitos en esta especie de coral esta significativamente influenciado por cambios en las condiciones ambientales de la región. Al respecto, el análisis evidenció que el porcentaje de colonias con actividad reproductiva tiene una alta correlación con el fotoperiodo $(R=0.739)$, y una relación inversa con el Kd490 $(R=-0.548)$, la TSM $(R=$ $0.49)$, el PAR $(R=0.324)$ y el porcentaje de iluminación lunar $(R=0.056)$. Lo anterior sugiere que, en el área de estudio, el patrón reproductivo de P. gigantea está relacionado principalmente con la extensión del fotoperiodo y en menor medida con la iluminación lunar (tabla 2).

\section{DISCUSIÓN}

En el área de estudio, las colonias de P. gigantea fueron gonocóricas, a excepción de una colonia hermafrodita observada en Estacahuite en julio de 2011. Tanto en la zona de estudio como en otros sitios del POT, se ha registrado un comportamiento reproductivo similar (Glynn et al. 1996, Rodríguez-Troncoso et al. 2011) denominado cosexualidad secuencial, donde los corales tienen la capacidad de iniciar su vida reproductiva como machos, subsecuentemente madurar como hermafroditas y consecuentemente generar colonias protándricas-hermafroditas (Fadlallah 1983, Harrison 2011). Se ha sugerido que la cosexualidad secuencial puede garantizar la reproducción sexual y aumentar la conectividad entre poblaciones (Fadlallah 1983, Harrison y Wallace 1990), pero también puede reducir la variabilidad genética y con ello aumentar la probabilidad de extirpación local o regional de la especie en cuestión. Debido a la baja cantidad de muestras hermafroditas en el presente trabajo y en los estudios previos, no se puede determinar con exactitud si $P$. gigantea tiene la capacidad para desarrollar cosexualidad secuencial, por lo que más estudios al respecto son necesarios.

En el área de estudio, P. gigantea mostró maduración sexual asincrónica. Esto concuerda con lo reportado previamente para las aguas frente a la costa sudoccidental de México (Rodríguez-Troncoso et al. 2011), pero difiere de la maduración sincrónica observada para la misma especie en el Pacífico frente a Centroamérica (Glynn et al. 1996) y la parte centro-occidental del México (Carpizo-Ituarte et al. 2011). La variación en el comportamiento reproductivo de la especie en la región puede ser ventajosa, pues le permite tener múltiples desoves durante su periodo reproductivo; además, la maduración asincrónica entre colonias de sexos distintos promueve el intercambio de material genético entre localidades (Harrison y Wallace 1990).

A diferencia de estudios previos frente a la costa occidental de México (Carpizo-Ituarte et al. 2011, RodríguezTroncoso et al. 2011), en el presente estudio se observaron los cuatro estadios de desarrollo de los ovocitos, así como 
Table 2. Correlation of environmental variables with the percentage of reproductively active colonies (\% RAC) in Pacific coastal waters off Oaxaca (Mexico). Upper diagonal, $P$ values; lower diagonal, correlation values. LI, lunar illumination; SST, sea surface temperature; Kd490, diffuse attenuation coefficient; PAR, photosynthetically active radiation; PP, photoperiod.

Tabla 2. Correlación de las variables ambientales con el porcentaje de colonias con actividad reproductiva (\% RAC) en aguas del Pacífico frente a la costa de Oaxaca, México. Diagonal superior, valores de P; diagonal inferior, valores de correlación. LI, luminosidad lunar; SST, temperatura superficial del mar; Kd490, coeficiente de atenuación difusa; PAR, radiación fotosintética disponible; PP, fotoperiodo.

\begin{tabular}{lllllll}
\hline & LI & SST & Kd490 & PAR & PP & \% RAC \\
\hline LI & & 0.632 & 0.796 & 0.820 & 0.526 & 0.826 \\
$\mathrm{~T}$ & 0.121 & & 0.00000124 & 0.246 & 0.0000330 & 0.0389 \\
Kd490 & -0.0656 & -0.883 & & 0.101 & 0.00000315 & 0.0186 \\
PAR & 0.0578 & 0.288 & -0.399 & & 0.0966 & 0.190 \\
PP & -0.160 & 0.818 & -0.867 & 0.404 & & 0.000457 \\
\% RAC & 0.0558 & 0.490 & -0.548 & 0.324 & 0.739 & \\
\hline
\end{tabular}

but differs from the synchronous maturation observed for the same species off the Pacific coast of Central America (Glynn et al. 1996) and central Mexico (Carpizo-Ituarte et al. 2011). A variation in reproductive behavior can be advantageous because it allows the species to undergo multiple spawns during the reproductive period. Moreover, asynchronous maturation among colonies of a different sex promotes the exchange of genetic material among sites (Harrison and Wallace 1990).

Unlike other studies conducted off the west coast of Mexico (Carpizo-Ituarte et al. 2011, Rodríguez-Troncoso et al. 2011), we observed the four stages of oocyte development as well as interstitial cells, which is indicative of oogenesis and spermatogenesis (Szmant-Froelich et al. 1985). The presence of the four maturation stages suggests that the environmental conditions in the study area were appropriate for successful gametogenesis, but may not have been sufficiently favorable for the completion of oocyte maturation and spawning.

The presence of mature male and female gametes at Estacahuite and Montosa Island in August 2011 suggests that both the final phase of gametogenesis and spawning may have occurred during this month, since the period of rest began in September 2011 at both sites. To date, it had not been possible to observe mature male and female sex cells in the same place at the same time, so these findings may be the first indication of the successful sexual reproduction of $P$. gigantea off the west coast of Mexico. Further studies are clearly needed, but August could be one of the months when gamete release occurs in the study area. The environmental conditions recorded in August were SST of $29.88^{\circ} \mathrm{C}$, photoperiod of $12.41 \mathrm{~h}$, and $99 \%$ lunar illumination, and these conditions may thus be favorable for oocytes to reach maturity stage IV. Numerical experiments have shown that particle transport occurs close to shore in August (Lara-Hernández 2012), and this could guarantee auto-recruitment as well as the connectivity with reef systems at higher latitudes (e.g., Zihuatanejo) (López-Pérez et al. 2012). células intersticiales, lo cual es indicativo de la producción de oogonias y espermatogonias (Szmant-Froelich et al. 1985). La presencia de los cuatro estadios de maduración sugiere que las condiciones ambientales en la zona de estudio fueron adecuadas para que la gametogénesis fuera exitosa, aunque pudieran no haber sido lo suficientemente favorables como para concluir la maduración de los ovocitos y el desove de los mismos.

Adicionalmente, la presencia de células sexuales maduras de ambos sexos en las localidades de Estacahuite e isla Montosa durante agosto de 2011 sugiere que tanto la fase final de la gametogénesis como el posible desove pudieron haberse llevado a cabo durante este mes, puesto que para septiembre del mismo año comenzó el periodo de reposo en ambas localidades. Los resultados anteriores podrían constituir el primer indicio de reproducción sexual exitosa de $P$. gigantea frente a la costa occidental de México, dado que a la fecha no había sido posible observar células sexuales maduras, femeninas y masculinas, en el mismo tiempo y espacio. Aunque son necesarios más estudios al respecto, agosto podría ser uno de los meses más probables para que se lleve a cabo la liberación de gametos en el área de estudio. Las condiciones ambientales en agosto fueron TSM de $29.88^{\circ} \mathrm{C}$, fotoperiodo de $12.41 \mathrm{~h}$ e iluminación lunar del $99 \%$, lo que sugiere que estas condiciones son favorables para que los ovocitos maduren a estadio IV. Según experimentos numéricos, el transporte de partículas en agosto es cercano a la costa (Lara-Hernández 2012), lo que podría garantizar el autoreclutamiento, además de la conectividad hacia sistemas arrecifales en latitudes más altas (i.e., Zihuatanejo) (López-Pérez et al. 2012).

Los resultados del presente estudio sugieren que el periodo reproductivo de $P$. gigantea está asociado a la variación estacional que ocurre en la región. La actividad reproductiva inició a finales de la época de secas, lo que coincide con fuertes vientos del norte, y se mantuvo durante la época de lluvias en verano. Aunque este es un comportamiento observado frente a la costa occidental de México 
Our results suggest that $P$. gigantea reproduces seasonally. Reproductive activity initiates at the end of the dry season (winter), during which northerly winds occur, and continues during the rainy season (summer). While this behavior has been observed along the Pacific coast of Mexico (Carpizo-Ituarte et al. 2011) and Central America (Glynn et al. 1996), previous studies in our study area indicate that the species can have both seasonal and monthly periods of gametogenesis (Glynn et al. 1996, Carpizo-Ituarte et al. 2011, Rodríguez-Troncoso et al. 2011). Overall, the results indicate that the reproductive activity of P. gigantea in the ETP occurs mainly during the warm season (Glynn et al. 1996, CarpizoItuarte et al. 2011, Rodríguez-Troncoso et al. 2011, this study), though it is sufficiently dynamic to vary in space and time possibly in response to oscillations in local and regional oceanographic conditions modulated by interannual variations. This statement is supported by the significant relationship between the percentage of reproductively active colonies (i.e., both sexes and females) of P. gigantea and the mesoscale seasonal and interannual variation in the study area, which indicates that the reproduction of this coral species in the region is linked to local environmental variations.

Contrary to that documented for other species from other areas (Levy et al. 2007), the relationship between reproductive activity and percentage of lunar illumination was the least significant. Several studies have reported a relationship between the lunar cycle and the reproductive cycle of corals (Stoddart and Black 1985); in fact, the perception of moonlight is fundamental for coral spawning (Harrison and Wallace 1990). On the other hand, the Kd490 values were inversely related to reproductive activity, contrary to the relationship between PAR and reproductive activity; that is, when the reproductive peaks were higher, the $\mathrm{Kd} 490$ values were close to zero and the PAR values were high. This indicates that light is likely important in determining the percentage of reproductively active $P$. gigantea colonies in the study area. Numerous studies have indicated that light is the main source of energy for hermatypic corals because symbionts use solar energy to fix carbon dioxide and metabolize it into oxygen and carbon compounds, which are then translocated to the coral cells (Yellowlees et al. 2008). Thus, symbionts contribute to the nutrition, respiration, growth, and reproduction of corals (Stat et al. 2008, Yellowlees et al. 2008, Stambler 2011). This contribution can be affected by turbidity levels, because when they increase they can also decrease, among other things, the symbiont's photosynthetic capacity. An increase in PAR, therefore, translates into greater energy for the host's metabolism.

In the present study, gametogenesis occurred when SST was between 28 and $31^{\circ} \mathrm{C}$. Similarly, Rodríguez-Troncoso et al. (2011) and Carpizo-Ituarte et al. (2011) reported that gametogenesis occurred when SST was $27^{\circ} \mathrm{C}$ in La Entrega Bay (Oaxaca, southwest Mexico) and $28.5^{\circ} \mathrm{C}$ in Banderas Bay (Nayarit, west-central Mexico), respectively.
(Carpizo-Ituarte et al. 2011) y de Centroamérica (Glynn et al. 1996), estudios previos en la zona de estudio indican que la especie puede tener periodos de gametogénesis tanto estacionales como mensuales (Glynn et al. 1996, Carpizo-Ituarte et al. 2011, Rodríguez-Troncoso et al. 2011). En conjunto, los resultados señalan que el comportamiento reproductivo de P. gigantea en el Pacífico oriental tropical ocurre preferentemente durante la temporada cálida (Glynn et al. 1996, Carpizo-Ituarte et al. 2011, Rodríguez-Troncoso et al. 2011, este estudio), aunque es lo suficientemente dinámico para variar en espacio y tiempo en relación con, posiblemente, oscilaciones en las condiciones oceanográficas locales y regionales moduladas por variaciones interanuales. Esto último es apoyado por la relación significativa observada entre el porcentaje de colonias con actividad reproductiva (i.e., ambos sexos y hembras) de $P$. gigantea y la variación estacional e interanual a mesoescala en la zona de estudio, lo cual indica que la reproducción de esta especie de coral en la región esta acoplada con las variaciones ambientales locales.

Contrario a lo que se ha observado en otras especies y áreas (Levy et al. 2007), la variable que mostró menor relación con la actividad reproductiva fue el porcentaje de iluminación lunar. Se ha documentado repetidas veces que la radiación lunar se relaciona con el ciclo reproductivo de corales (Stoddart y Black 1985); de hecho, la percepción de la luz lunar es fundamental para el desove de los corales (Harrison y Wallace 1990). Por otro lado, los valores de Kd490 se relacionaron de manera inversa con la actividad reproductiva, lo cual resultó contrario a la relación de PAR con la actividad reproductiva; es decir, cuando los picos reproductivos fueron mayores, los valores de Kd490 estuvieron cercanos a cero y los de la PAR fueron elevados. Lo anterior indica que la luz puede ser de suma importancia para determinar el porcentaje de colonias de P. gigantea con actividad reproductiva en la zona de estudio. Existe una miríada de estudios que indican que la luz representa la fuente principal de energía en corales hermatípicos ya que los simbiontes utilizan energía solar para fijar dióxido de carbono y metabolizarlo en oxígeno y en compuestos de carbono, los cuales son translocados a las células del coral (Yellowlees et al. 2008). De esta manera, los simbiontes contribuyen a la nutrición, respiración, crecimiento y reproducción de los corales (Stat et al. 2008, Yellowlees et al. 2008, Stambler 2011). Esta contribución puede verse afectada por los niveles de turbidez que, al aumentar, pueden disminuir, entre otras cosas, la capacidad fotosintética del simbionte; así, un aumento en la PAR puede traducirse en mayor energía para el metabolismo del hospedero.

Durante este estudio, la gametogénesis ocurrió cuando la TSM fue de 28 a $31{ }^{\circ} \mathrm{C}$. Esto concuerda con RodríguezTroncoso et al. (2011) y Carpizo-Ituarte et al. (2011), quienes registraron, respectivamente, que la gametogénesis ocurrió cuando la TSM fue de $27{ }^{\circ} \mathrm{C}$ frente a la zona sur (La Entrega, Oaxaca) y $28.5^{\circ} \mathrm{C}$ frente a la zona central (bahía Banderas, Nayarit) de la costa occidental de México. 
We found that photoperiod was the variable that most influenced the reproductive activity of $P$. gigantea. Symbionts are the main energy source for stony corals (Muscatine 1990, Stambler 2011); in fact, the energy transferred by Symbiodinium to the coral cells covers the host's daily energetic requirements and contributes to the reproductive activity. Photoperiod, together with other environmental conditions in the Gulf of Tehuantepec, could act as a synchronizer of the gametogenic cycle, as suggested by Benítez-Villalobos and Martínez-García (2012) for other invertebrates. Moreover, photoperiod in combination with warm temperatures could modulate gamete maturation in the region.

Our findings show that the reproductive activity of P. gigantea is driven by seasonal and interannual changes that occur in the Gulf of Tehuantepec, as has also been documented for other coral species and other regions (Harrison and Wallace 1990). Whether this environmental pattern drives the reproductive activity of other reef-building corals in the region (i.e., Pocillopora spp., Porites spp.) has yet to be determined. This type of information is relevant at both a local (i.e., Oaxaca) and regional scale because the connectivity among coral reef populations of the ETP depends on good management practices.

\section{ACKNOWLEDGMENTS}

This study was supported by the National Council for Science and Technology (CONACYT, Mexico, project 80228 headed by ALP). JDSV was supported by a scholarship from CONACYT (No. 18410). We thank Denise Zavala for her help in processing the samples.

\section{English translation by Christine Harris.}

\section{REFERENCES}

Benítez-Villalobos F, Martínez-García M. 2012. Reproductive biology of the starfih Pharia pyramidatus (Echinodermata: Asteroidea) from the Mexican Tropical Pacific. J. Mar. Biol. Assoc. UK 92(6): 1409-1418.

Carpizo-Ituarte E, Vizcaíno-Ochoa V, Chi-Barragán G, TapiaVázquez O, Cupul-Magaña AL, Medina-Rosas P. 2011. Evidence of sexual reproduction in the hermatypic corals Pocillopora damicornis, Porites panamensis, and Pavona gigantea in Banderas Bay, Mexican Pacific. Cienc. Mar. 37: 97-112. http://dx.doi.org/10.7773/cm.v37i1.1773

Cortés J. 1997. Biology and geology of eastern Pacific coral reefs. Coral Reefs 16: S39-S46.

Fadlallah YH. 1983. Sexual reproduction, development and larval biology in scleractinian corals. Coral Reefs 2: 129-150.

Fernández-Álamo MA, Farber-Lorda J. 2006. Zooplankton and the oceanography of the eastern tropical Pacific: A review. Prog. Oceanogr. 69: 318-359.

García E. 1973. Modificaciones al sistema de clasificación climática de Köpen (para adaptarlo a las condiciones de la República Mexicana). Instituto de Geografía, Universidad Nacional Autónoma de México, 264 pp.
La variable que mostró la mayor relevancia en la actividad reproductiva de $P$. gigantea en la región de estudio fue el fotoperiodo. Los simbiontes son los proveedores energéticos más importantes para los corales pétreos (Muscatine 1990, Stambler 2011); de hecho, la energía que transfiere Symbiodinium al hospedero cubre los requerimientos energéticos diarios del coral y, además, contribuye con la actividad reproductiva. Adicionalmente, el fotoperiodo junto con otras condiciones ambientales del golfo de Tehuantepec puede actuar como sincronizador del ciclo gametogénico, como ha sido sugerido por Benítez-Villalobos y MartínezGarcía (2012) para otros invertebrados. Pudiera ser el caso, también, que el fotoperiodo se combine con temperaturas cálidas y así module la maduración de gametos en la región.

El presente estudio demostró que la actividad reproductiva de $P$. gigantea se desarrolló en respuesta a los cambios estacionales e interanuales a mesoescala que ocurren en el golfo de Tehuantepec, lo cual concuerda con lo observado en otras especies de coral y para otras regiones (Harrison y Wallace 1990). Queda por resolver si este mismo patrón ambiental gobierna la actividad reproductiva de otras especies de coral que construyen arrecifes en la región (i.e., Pocillopora spp., Porites spp.). Este tipo de información es relevante no solo a nivel local (i.e., Oaxaca), sino también regional, ya que la conectividad entre las comunidades y arrecifes coralinos del POT depende del buen manejo de sistemas.

\section{Agradecimientos}

El Consejo Nacional de Ciencia y Tecnología (CONACYT, México) brindó apoyo financiero a través de una beca (no. 18410) al primer autor y del proyecto (no. 80228 ) a cargo de ALP. Agradecemos a Denise Zavala su apoyo en el tratamiento de las muestras.

Glynn PW, Leyte-Morales GE. 1997. Coral reefs of Huatulco, West Mexico: Reef development in upwelling Gulf of Tehuantepec. Rev. Biol. Trop. 45(3): 1033-1047.

Glynn PW, Ault JS. 2000. A biogeographic analysis and review of the far eastern Pacific coral reef region. Coral Reefs 19: 1-23.

Glynn PW, Colley SB, Gassman NJ, Black K, Cortés J, Mate JL. 1996. Reef coral reproduction in the eastern Pacific: Costa Rica, Panamá and Galápagos Islands (Ecuador). III. Agariciidae (Pavona gigantea and Gardineroseris planulata). Mar. Biol. 125: 579-601.

Glynn PW, Colley SB, Ting JH, Maté JL, Guzmán HM. 2000. Reef coral reproduction in the eastern Pacific: Costa Rica, Panamá, and Galápagos Islands (Ecuador). IV. Agariciidae recruitment and recovery of Pavona varians and Pavona spp. Mar. Biol. 136: 785-805.

Harrison PC, Wallace CC. 1990. Reproduction, dispersal and recruitment of scleractinian corals. In: Dubinsky $\mathrm{Z}$ (ed.), Ecosystems of the World 25. Coral Reefs. Elsevier, Amsterdam, pp. 133-207.

Harrison PC, Babcock RC, Bull GD, Oliver JK, Valle CC, Willis BL. 1984. Mass spawning in tropical reef corals. Science 464: 221-224. 
Harrison PL. 2011. Sexual reproduction of scleractinian corals. In: Dubinsky Z, Stambler N (eds.), Coral Reefs: An Ecosystem in Transition. Springer, New York, pp. 59-85.

Kessler WS. 2002. Mean three-dimensional circulation in the Northeast Tropical Pacific. J. Phys. Oceanogr. 32: 2457-2471.

Lara-Hernández JA. 2012. Transporte larvario y conectividad potencial de corales pétreos en el Pacífico Mexicano: Estudio mediante simulaciones numéricas. BSc thesis, Universidad del Mar, México, 100 pp.

Levy O, Appelbaum L, Leggat W, Gothlif Y, Hayward DC, Miller DJ, Hoegh-Guldberg O. 2007. Light-responsive cryptochromes from a simple multicellular animal, the coral Acropora millepora. Science 318: 467-70.

López-López DA. 2011. Bioerosión provocada por el erizo Diadema mexicanum A. Agassiz, 1863 en localidades de Oaxaca y Guerrero. BSc thesis, Universidad del Mar, México, $65 \mathrm{pp}$.

López-Pérez RA, Hernández-Ballesteros LM. 2004. Coral community structure and dynamics in the Huatulco area, western Mexico. Bull. Mar. Sci. 75: 453-472.

López-Pérez RA, Calderón-Aguilera LE, Reyes-Bonilla $H$, Carriquiry JD, Medina-Rosas P, Cupul-Magaña AL, HerreroPérezrul MD, Hernández-Ramírez HA, Ahumada-Sempoal MA, Luna-Salguero BM. 2012. Coral communities and reefs from Guerrero, southern Mexican Pacific. Mar. Ecol. 33(4): 407-416. http://dx.doi.org/10.1111/j.1439-0485.2011.00505.x

Muscatine L. 1990.The role of symbiotic algae in carbon and energy flux in reef corals. In: Dubinsky Z (ed.), Coral Reefs. Elsevier, Dordrecht, pp. 75-87.

Reyes-Bonilla H, López-Pérez RA. 1998. Biogeography of the stony corals (Scleractinia) of the Mexican Pacific. Cienc. Mar. 24: 211-224.

Reyes-Bonilla H, Calderón-Aguilera LE, Cruz-Piñon G, Medina Rosas P, López-Pérez RA, Herrero-Pérez MD, Leyte-Morales GE, Cupul-Magaña AL,Carriquiry-Beltrán JD. 2005. Atlas de los Corales Pétreos (Anthozoa: Scleractinia) del Pacífico Mexicano. CICESE, CONABIO, CONACYT, DBM/UABCS, CUC/Univ. de Guadalajara, Univ. del Mar, México, 124 pp.
Rodríguez-Troncoso AP, Carpizo-Ituarte E, Leyte-Morales GE, ChiBarragán G, Tapia-Vázquez O. 2011. Sexual reproduction of three coral species from the Mexican South Pacific. Mar. Biol. 158: $2673-2683$. http://dx.doi.org/10.1007/s00227-011-1765-9

Saavedra-Sotelo N, Calderón-Aguilera L, Reyes-Bonilla H, LópezPérez A, Medina-Rosas P, Rocha-Olivares A. 2011. Limited genetic connectivity of Pavona gigantea in the Mexican Pacific. Coral Reefs, 30: 677-686.

Somero GN. 2005. Linking biogeography to physiology: Evolutionary and acclimatory adjustments of thermal limits. Front. Zool. 2: 1. http://dx. doi. org/10.1186/1742-9994-2-1

Stambler N. 2011. Zooxanthellae: The yellow symbionts inside animals. In: Dubinsky Z, Stambler N (eds.), Coral Reefs. An Ecosystem in Transition. Springer, New York, pp. 87-106. http://dx.doi.org/ 10.1007/978-94-007-0114-4

Stat M, Loh WKW, Hoegh-Guldberg O, Carter DA. 2008. Symbiont acquisition strategy drives host-symbiont associations in the southern Great Barrier Reef. Coral Reefs 27: 763-772.

Steenburgh WJ, Schultz DM, Colle BA. 1998. The structure and evolution of gap outflow over the Gulf of Tehuantepec, Mexico. Mon. Weather Rev. 126: 2673-2691.

Stoddart JA, Black R. 1985. Cycles of gametogenesis and planulation in the coral Pocillopora damicornis. Mar. Ecol. Prog. Ser. 23: 153-164.

Szmant-Froelich A, Reutter M, Riggs S. 1985. Sexual reproduction of Favia fragum (Esper): Lunar patterns of gametogenesis, embryogenesis and planulation in Puerto Rico. Bull. Mar. Sci. 37:

$880-892$.

Tanner JE. 1996. Seasonality and lunar periodicity in the reproduction of Pocilloporid corals. Coral Reefs. 15: 59-66.

Tapia-García M, García-Abad MC, Carranza-Edwards A, VázquezGutiérrez F. 2007. Environmental characterization of the continental shelf of the Gulf of Tehuantepec, Mexico. Geo. Int. 46(4): 249-260.

Yellowlees D, Rees TAV, Leggat W. 2008. Metabolic interactions between algal symbionts and invertebrate hosts. Plant Cell Environ. 31: 679-694.

Received October 2014, accepted April 2015. 